\title{
The Use of Fatty Acid Profile as a Potential Marker for Brazilian Coffee (Coffea arabica L.) for Corn Adulteration
}

\author{
Gulab N. Jham, *,\# Mark A. Berhow, Linda K. Manthey, Deborah A. Palmquist and Steven F. Vaughn \\ United States Department of Agriculture, NCAUR, Peoria, IL 61604, USA
}

\begin{abstract}
A composição de ésteres metílicos de ácidos graxos (EMAGs) das variedades de café (Coffea arabica L.) Catuai, Catucaí, Bourbom, Mundo Novo, Rubí e Topázio conhecidas por produzirem bebidas de qualidade intermediária, ótima, ótima, intermediária, intermediária e inferior, respectivamente, foi determinada pela primeira vez. A $(\%)$ de área média dos seguintes ácidos das seis variedades foi: palmítico $(38,2)$, esteárico $(8,3)$, oléico $(8,7)$, linoléico $(38,5)$, linolênico $(1,6)$ e araquidônico $(3,6)$, respectivamente. O método é bastante rápido, com a completa caracterização das amostras estudadas (99\%) ocorrendo em menos de 6 minutos. Enquanto esses valores podem fornecer informação para a avaliação da qualidade do café, nenhum efeito significativo $(\mathrm{p}<0,05)$ da variedade de café foi encontrado na (\%) de área das EMAGs. Além disso, foram comparados os EMAGs de: seis amostras de milho, seis marcas de café comerciais e uma amostra de café comercial intencionalmente adulterada com três quantidades de milho. Apesar da razão ácido linoléico/ácido esteárico encontrada nos EMAGs do café e do milho serem significativamente diferentes, não foi possível utilizar esse marcador para detectar adulteração do milho em cafés comerciais.
\end{abstract}

Fatty acid methyl ester (FAME) composition of the coffee (Coffea arabica L.) varieties Catuai, Catucaí, Bourbom, Mundo Novo, Rubí and Topázio known to produce beverage of intermediate, excellent, excellent, intermediate, intermediate and poor quality, respectively, was determined for the first time. Average area \% of the FAMEs of the six varieties was: palmitic (38.2), stearic (8.3), oleic (8.6), linoleic (38.5), linolenic (1.6) and arachidic (3.6) acids, respectively. The method was very quick with complete characterization $(>99 \%)$ of the samples studied being possible in less than $6 \mathrm{~min}$. While these values may provide insights for evaluating the coffee quality, no significant effect $(\mathrm{p}<0.05)$ of coffee variety was found on area $\%$ of the FAMEs. In addition, FAMEs of six corn samples, six commercial coffee brands and one commercial coffee sample intentionally contaminated with three levels of corn were compared. Although the linoleic/stearic ratio was significantly different in coffee and corn FAMEs, this probe could not be used a marker to detect corn adulteration in commercial coffees.

Keywords: coffee, coffee quality, fatty acids, corn, adulteration

\section{Introduction}

Coffee (Coffea arabica, L.) quality may be lowered through hydrolysis of triacylglycerols (TAGs) resulting in release of free fatty acids (FAs) which are oxidized to produce off-flavor. ${ }^{1}$ However, no studies have been conducted relating FAs to coffee quality despite the fact that they are known to be important flavor components. ${ }^{2}$ Coffee quality can also be lowered by adulteration with cereals, coffee twigs, caramel, etc. This practice may be widespread in Brazil, with corn being considered the most widely used adulterant, due to

*e-mail: gulab@ufv.br

\# Permanent address: Universidade Federal de Viçosa, Departamento de Química, Viçosa-MG, Brazil its significantly lower cost. Few studies have been reported detecting corn in coffee $e^{3-5}$ but only one study has detected corn commercial coffees using $\gamma$-tocopherols as the probe. ${ }^{6}$ Our coffee program studies the role of fatty acids in coffee flavors and also develops chromatographic methods to detect corn as an adulterant in coffee.

In this study, we report for the first time the fatty acid methyl ester (FAME) composition of the coffee (Coffea arabica L.) varieties Catuai, Catucaí, Bourbom, Mundo Novo, Rubí and Topázio known to produce beverage of intermediate, excellent, intermediate, intermediate and poor quality, respectively, was determined for the first time. The coffee FA composition found in this study was significantly 
different from that of corn. ${ }^{7}$ This difference opened the possibility of using FAs as indicators of coffee adulteration by corn as in the case with olive oil FAs. ${ }^{8}$

\section{Experimental}

\section{Chemicals}

HPLC-grade hexane and methanol, FAME standards were purchased from Sigma-Aldrich, Inc. (St. Louis, $\mathrm{MO})$.

\section{Coffee and corn samples}

The roasting, grinding, and extraction processes described below were performed in triplicate for each sample and/or variety.

\section{Six coffee varieties}

About $1 \mathrm{~kg}$ of six green coffee (C. arabica) bean varieties (Catuai, Catucaí, Bourbom, Mundo Novo, Rubí and Topázio) were supplied by Incofex Inc. (Viçosa, MG, Brazil). The samples were divided into roughly three equal parts. Each part was roasted at $180^{\circ} \mathrm{C}$ for $10 \mathrm{~min}$ in a coffee roaster with three burners, ground in a coffee grinder.

\section{Commercial coffee brands}

One $\mathrm{kg}$ of six roasted and ground coffee (C. arabica) popular local brands was purchased from a local supermarket in Viçosa, MG, Brazil. All samples were divided into roughly three equal portions.

\section{Intentionally adulterated coffee ( $C$. arabica) sample}

A commercial coffee brand was mixed with 5, 10 and $20 \%$ of ground roasted corn (m:m, corn:coffee).

\section{Commercial corn}

One kg of six commercial corn samples was randomly selected from a local supermarket in Viçosa, MG, Brazil. The samples were divided into roughly three equal portions, roasted and ground under the conditions the same conditions utilized for coffee.

\section{Oil extraction}

About $10 \mathrm{~g}$ of all the samples were extracted overnight separately with hexane in a Soxhlet extractor. After cooling, the solution was dried over anhydrous sodium sulphate, and evaporated under reduced pressure at $35^{\circ} \mathrm{C}$ to obtain oils, which were sealed under $\mathrm{N}_{2}$, and stored in a freezer $\left(-5^{\circ} \mathrm{C}\right)$ until analysis.

\section{Instrument reproducibility}

The reproducibility of the gas chromatographs was verified by analyzing 10 times the FAMES of a randomly chosen sample. The standard deviation (SD) obtained in the area $\%$ of FAMEs was calculated.

\section{FAMEs}

Fatty acid methyl esters were analyzed by gas chromatography (GC) by placing $10 \mathrm{mg}$ of oil in a $2 \mathrm{~mL}$ crimp cap vial then adding $1.0 \mathrm{~mL}$ of $0.25 \mathrm{~mol} \mathrm{~L}^{-1}$ sodium methoxide solution. The vial was sealed with a crimp cap and placed in a heating block that was maintained at $60^{\circ} \mathrm{C}$. After 30 minutes the vial was removed from the heating block allowed to cool to room temperature and $1.0 \mathrm{~mL}$ of $0.25 \mathrm{~mol} \mathrm{~L}^{-1}$ hydrochloric acid and $2 \mathrm{~mL}$ of hexane were added. The contents of the vial were agitated thoroughly for 2 min on a Vortex mixer and then allowed to separate. The top organic layer was drawn off and placed in a $2 \mathrm{~mL}$ GC vial and analyzed by GC under the conditions described below.

Fatty acid esters were analyzed by $\mathrm{GC}$ with a fused silica capillary column $(30 \mathrm{~m} \times 0.25 \mathrm{~mm}$ ID $\times 0.25 \mu \mathrm{m})$ coated with the SP 2380 stationary phase. The oven temperature was programmed ramped from 180 to $210^{\circ} \mathrm{C}$ at $7{ }^{\circ} \mathrm{C} \mathrm{min}^{-1}$, from 210 to $265^{\circ} \mathrm{C}$ at $30^{\circ} \mathrm{C} \mathrm{min}^{-1}$ and held $3 \mathrm{~min}$ at $265^{\circ} \mathrm{C}$. The injector was maintained at $250^{\circ} \mathrm{C}$ and $1 \mu \mathrm{L}$ injections were made with a split ratio of 100:1. Column flow rate of $1.4 \mathrm{~mL} \mathrm{~min}^{-1}$ with a split flow of $200 \mathrm{~mL} \mathrm{~min}{ }^{-1}$ (split ratio of 142:1) and a septum purge of $4 \mathrm{~mL} \mathrm{~min}^{-1}$. Analytes were detected by flame ionization with a detector temperature of $250^{\circ} \mathrm{C}$. Helium was used as the carrier gas at linear velocity of $35 \mathrm{~cm} \mathrm{~s}^{-1}$. Analytes were identified by comparison to known standards. Samples were analyzed in duplicate and results averaged. Area \% of the FAMEs were determined by summing the peak areas corresponding to the eight fatty acids identified, dividing each area by the total area of the FAMEs peaks and multiplying by 100 .

\section{Experimental design}

A Completely Random Design (CRD) was used to examine differences in relative percentage of 6 fatty acid methyl ester (FAME) types (C16:0, C18:0, C18:1, C18:2, $\mathrm{C} 20: 0$ and $\mathrm{C} 18: 3)$ and $\mathrm{C} 18: 1 / \mathrm{C} 18: 0$ ratios for roasted coffee, roasted corn, and 3 compositions of coffee and corn (95\% coffee $+5 \%$ corn, $90 \%$ coffee $+10 \%$ corn, and $80 \%$ coffee $+20 \%$ corn). Six roasted coffee varieties/brands, as well as six roasted corn brands were used as replicates. The coffee + corn compositions used 3 sample replicates. 


\section{Statistical analyses}

Single-factor, mixed model analyses of variance (ANOVAs) were conducted comparing relative percentage of FAME types and FAME ratios for coffee, corn, and coffee/corn compositions. If a F-test statistic was significant at $\mathrm{p} \leq 0.05$, the FAME types and ratios were declared statistically different.

A two-factor, mixed model ANOVA was used to examine FAME ratio and coffee/corn composition interaction. If a significant F-test statistic was obtained at $\mathrm{p} \leq 0.05$ for the interaction, no FAME ratio or coffee/corn composition main effects were examined.

Differences of least squares means at $\mathrm{p} \leq 0.05$ was used as the pairwise multiple comparison procedure when a significant F-statistic was obtained from any ANOVA. A Bonferroni adjustment to the p-value was made when the number of comparisons was large.

Coffee varieties and corn brands in the FAME singlefactor ANOVA analyses were considered to be random effects whose contribution to the residual experimental error were either negligible or zero, indicating no significant differences between the coffee varieties or corn brands.

Levene's homogeneity of variance test was performed on all data to determine if transformations were needed before any ANOVAs were conducted. All analyses were performed on transformed data where necessary, but raw data means and standard deviations are presented for ease of interpretation. All analyses were performed using $\mathrm{SAS}^{\circledR}$ PC Windows Version 9.1.3 software.

\section{Results and Discussion}

\section{FAMEs in six coffee varieties}

Typical chromatogram obtained on GC analysis of coffee and corn FAMEs are presented in Figure 1. As it can be observed the GC run time was very short, i.e. 6 min. A smooth base line and good reproducibility was obtained with all the samples. The instrument functioned adequately as a small SD in the TAG area percentages was obtained when a randomly chosen coffee oil was injected ten times successively. For the FAMEs present in minor (ca. 0.2\%) to moderate amounts ( $c a .10 \%$ ) the SD was about 0.1 while for the major FAMEs it was about 0.6. With the coffee samples, the SDs tended to be slightly larger but still very low and acceptable. Good reproducibility, precision and low SD made this method suitable to quantify FAs.

To evaluate possible correlations between coffee qualities with FAs, we chose six widely used coffee varieties (Catuai, Catucaí, Bourbom, Mundo Novo, Rubí and Topázio).
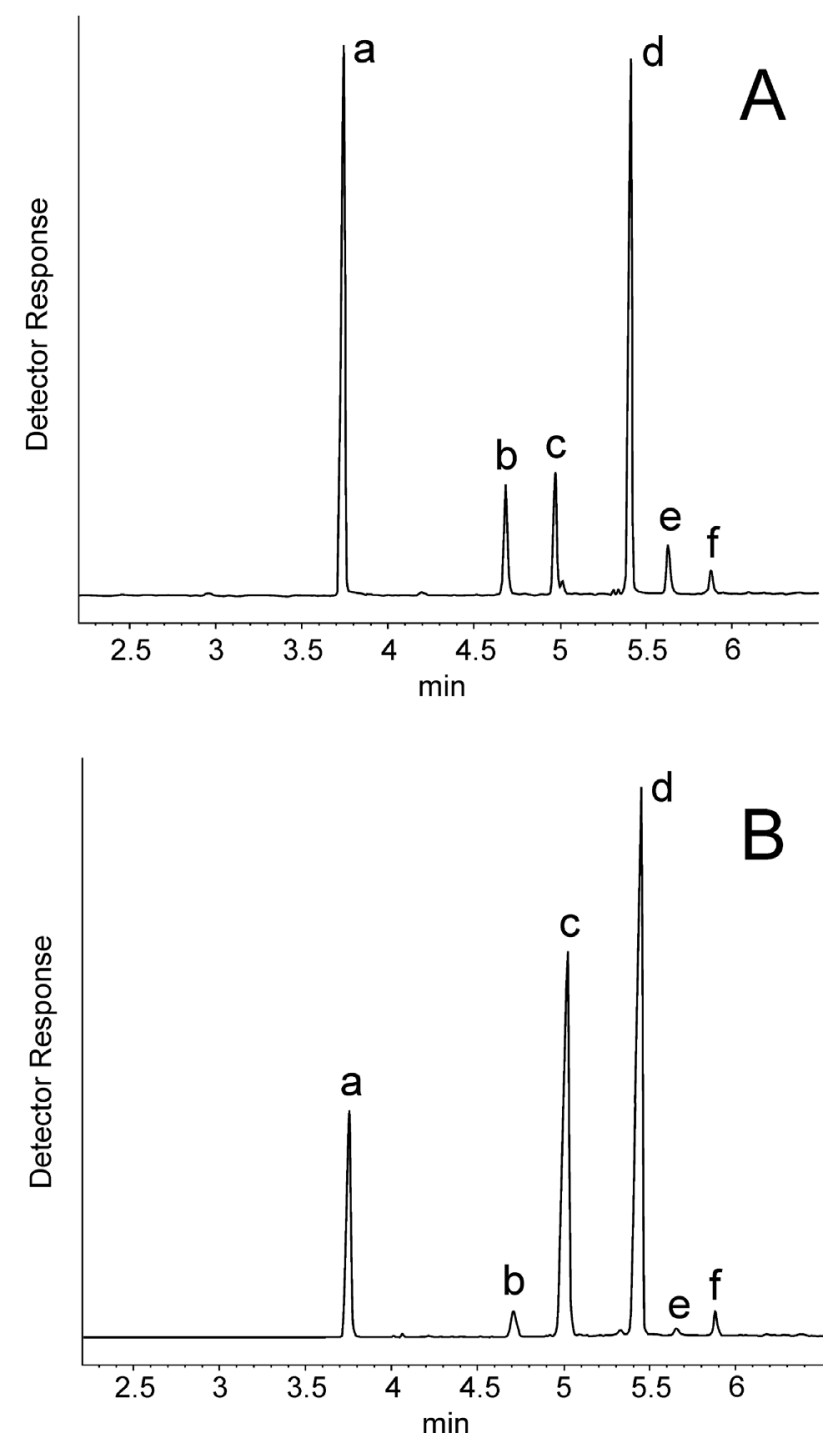

Figure 1. Typical gas chromatogram obtained on analysis of FAMEs from coffee (A) and corn (B) using a fused silica capillary column $(30 \mathrm{~m} \times 0.25 \mathrm{~mm} \mathrm{ID} \times 0.25 \mu \mathrm{m})$ coated with the SP 2380 stationary phase. The oven temperature was programmed ramped from 180 to $210^{\circ} \mathrm{C}$ at $7^{\circ} \mathrm{C} \mathrm{min}{ }^{-1}$, from 210 to $265^{\circ} \mathrm{C}$ at $30^{\circ} \mathrm{C} \mathrm{min}^{-1}$ and held 3 min at $265^{\circ} \mathrm{C}$. The injector was maintained at $250^{\circ} \mathrm{C}$ and $1 \mu \mathrm{L}$ injections were made with a split ratio of 100:1. Column flow rate of $1.4 \mathrm{~mL} \mathrm{~min}^{-1}$ with a split flow of $200 \mathrm{~mL} \mathrm{~min}^{-1}$ (split ratio of 142:1) and a septum purge of $4 \mathrm{~mL} \mathrm{~min}^{-1}$ were used to separate the fatty ester isomers. Analytes were detected by flame ionization with a detector temperature of $250^{\circ} \mathrm{C}$. Helium carrier gas was used with a linear velocity of $35 \mathrm{~cm} \mathrm{~s}^{-1}$. Peak identification a: palimitic acid (C16:0), b: stearic acid (C18:0), c: oleic (C18:1), d: linoleic acid (C18:2), e: arachidic (C20:0) and f: linolenic (C18:3) acids, respectively.

The coffee varieties Catuai, Catucaí, Bourbom, Mundo Novo, Rubí and Topázio known to produce beverage of intermediate, excellent, intermediate, intermediate and poor quality, respectively. No significant effect of coffee variety was found on the area \% of the FAMEs (Table 1). Six fatty acids (elution order), i.e., C16:0 (palmitic), C18:0 (stearic), C18:1 (oleic), C18:2 (linoleic), C18:3 (linlolenic) and C20:0 (arachidic) were found in all the samples analyzed, with their average area $\%$ being 38.2 , 
8.3, 8.7, 38.5, 1.6 and 3.6, respectively. Palmitic and linoleic were the major fatty acids constituting about $76 \%$ of the total fatty acids, while stearic and oleic were present in moderate quantities and the rest of the fatty acids in small amounts. These results are in agreement with those of the literature. ${ }^{9-12}$

\section{Potential of FAMEs as adulterant markers}

Adulteration detection in coffee has been limited to distinguishing between $C$. arabica and $C$. robusta coffees. ${ }^{12-19}$ The only chemical method able to detect corn in coffee, based on $\gamma$-tocopherol was described by us recently. ${ }^{6}$ In that study, one out of six commercial coffees examined was adulterated with $8.9 \%$ corn. Hence, using the same coffee and corn samples, we could quickly evaluate the potential of any chemical marker to detect corn in coffee. Since large differences in coffee FAMEs and $\operatorname{corn}^{8}$ were noted, we decided to evaluate the potential of FAMEs as adulterant markers using the same samples and procedures described in our previous study. ${ }^{6}$ Several ratios were evaluated but the most consistent results were obtained with C18:1/C18:0 (linoleic acid/stearic acid).

The following steps were conducted to evaluate the potential of FAMEs as adulterants: $i$ ) determine C18:1/ C18:0 ratios in six unadulterated coffee varieties utilizing their averages as base line values; ii) determine C18:1/ C18:0 ratios in six roasted unadulterated corn utilizing their averages as base line values; $i i i)$ determine if $\mathrm{C} 18: 1 /$ $\mathrm{C} 18: 0$ ratios increased linearly in an unadulterated roasted coffee intentionally adulterated with three corn levels $(5,10$ and 20\%); iv) determine C18:1/C18:0 in six commercial coffee brands, knowing that only one of the samples (sample 3) was contaminated with $8.9 \%$ corn $^{6}$ and $v$ ) quantify corn in commercial coffee samples if C18:1/C18:0 ratios differed significantly from those of unadulterated coffees.

FAMEs area $\%$ and the $\mathrm{C} 18: 1 / \mathrm{C} 18: 0$ ratios for six varieties of roasted Brazilian coffee (Coffea arabica L.), six roasted Brazilian corn samples, three intentionally adulterated Brazilian coffee (Coffea arabica L.) samples and six roasted Brazilian coffee (Coffea arabica L.) brands are presented in Table 2. The average area \% of C16:0, C18:0, C18:1, C18:2, C20:0 and C18:3 for six coffee varieties was: $38.2,8.3,8.6,38.5,1.6$ and 3.6 , respectively; while that for corn brands was 14.6, 2.2, 33.3, 47.2, 0.6 and 1.6, respectively. Similarly the C18:1/C18:0 ratios in coffee and corn were 1.0 and 15.7, respectively. Since large differences in $\mathrm{C} 18: 1 / \mathrm{C} 18: 0$ ratios were obtained between coffee and corn, the potential of using this ratio as a marker of adulteration was investigated. Hence we first evaluated if C18:1/C18:0 ratios could detect corn in an intentionally adulterated coffee adulterated with 5, 10 and 20\% roasted corn. The $\%$ contamination was arbitrarily chosen and based on the supposition that it had to be sufficiently high for a financial return but at the same time could not be too high as to significantly alter coffee flavor.

The results with the intentionally adulterated samples are presented in Table 2. As expected, a linear increase in C18:1/C18:0 with \% roasted corn added was obtained that could be described by the equation $\mathrm{Y}=0.945+$ $0.01214 \mathrm{X}$, where $\mathrm{Y}$ is the $\mathrm{C} 18: 1 / \mathrm{C} 18: 0$ and $\mathrm{X}$ is the corn $\%$ contamination level. The standard error for the intercept and concentration were 0.00982 and 0.000742 , respectively, and the correlation coefficient $\left(\mathrm{R}^{2}\right)$ was 0.996 . Hence, it appeared that $\mathrm{C} 18: 1 / \mathrm{C} 18: 0$ presented potential

Table 1. Mean area \% of FAMEs (fatty acid methyl esters)* and C18:1/C18:0 ratios in six roasted Brazilian coffee (Coffea arabica L.) varieties (Catuai, Catucaí, Bourbom, Mundo Novo, Rubí and Topázio) and six roasted Brazilian corn samples

\begin{tabular}{|c|c|c|c|c|c|c|c|c|c|c|c|c|}
\hline \multirow{2}{*}{$\begin{array}{l}\text { FAMEs } \\
\text { (elution } \\
\text { order) }\end{array}$} & \multicolumn{6}{|c|}{ Coffee varieties } & \multicolumn{6}{|c|}{ Corn brands } \\
\hline & $\mathrm{i}$ & ii & iii & iv & $\mathrm{v}$ & vi & $\mathrm{i}$ & ii & iii & iv & $\mathrm{v}$ & vi \\
\hline C16:0 & $36.6 \pm 2.2$ & $37.1 \pm 0.7$ & $37.8 \pm 0.2$ & $39.3 \pm 1.6$ & $39.2 \pm 1.2$ & $39.4 \pm 1.0$ & $14.6 \pm 0.4$ & $14.7 \pm 0.3$ & $14.4 \pm 0.1$ & $14.6 \pm 0.5$ & $14.8 \pm 0.2$ & $14.4 \pm 0.3$ \\
\hline $\mathrm{C} 18: 0$ & $8.2 \pm 0.1$ & $8.1 \pm 0.1$ & $8.3 \pm 0.1$ & $8.2 \pm 0.2$ & $8.3 \pm 0.1$ & $8.5 \pm 0.2$ & $2.2 \pm 0.3$ & $2.1 \pm 0.03$ & $2.1 \pm 0.04$ & $2.1 \pm 0.1$ & $2.1 \pm 0.01$ & $2.2 \pm 0.03$ \\
\hline $\mathrm{C} 18: 1$ & $8.9 \pm 0.3$ & $9.0 \pm 0.04$ & $8.9 \pm 0.04$ & $8.4 \pm 0.1$ & $8.4 \pm 0.1$ & $8.3 \pm 0.2$ & $33.3 \pm 0.6$ & $32.9 \pm 0.1$ & $33.4 \pm 0.2$ & $32.9 \pm 0.6$ & $33.6 \pm 0.4$ & $33.8 \pm 0.1$ \\
\hline C18:2 & $40.2 \pm 2.5$ & $39.9 \pm 0.7$ & $38.7 \pm 0.5$ & $37.8 \pm 1.7$ & $37.7 \pm 1.3$ & $37.0 \pm 1.8$ & $47.2 \pm 1.2$ & $47.7 \pm 0.4$ & $47.7 \pm 0.2$ & $47.7 \pm 0.3$ & $47.2 \pm 0.4$ & $47.4 \pm 0.2$ \\
\hline $\mathrm{C} 20: 0$ & $3.3 \pm 0.4$ & $3.3 \pm 0.03$ & $3.6 \pm 0.2$ & $3.6 \pm 0.1$ & $3.7 \pm 0.1$ & $3.9 \pm 0.6$ & $0.6 \pm 0.01$ & $0.6 \pm 0.03$ & $0.6 \pm 0.04$ & $0.6 \pm 0.1$ & $0.5 \pm 0.1$ & $0.5 \pm 0.01$ \\
\hline $\mathrm{C} 18: 3$ & $1.6 \pm 0.1$ & $1.6 \pm 0.03$ & $1.6 \pm 0.02$ & $1.7 \pm 0.1$ & $1.5 \pm 0.1$ & $1.7 \pm 0.2$ & $1.6 \pm 0.2$ & $1.5 \pm 0.03$ & $1.5 \pm 0.02$ & $1.6 \pm 0.1$ & $1.5 \pm 0.05$ & $1.5 \pm 0.04$ \\
\hline $\begin{array}{l}\text { C18:1/ } \\
\text { C18:0 }\end{array}$ & $1.1 \pm 0.04$ & $1.1 \pm 0.02$ & $1.1 \pm 0.01$ & $1.0 \pm 0.03$ & $1.0 \pm 0.02$ & $1.0 \pm 0.04$ & $15.4 \pm 1.7$ & $15.9 \pm 0.3$ & $16.1 \pm 0.2$ & $15.5 \pm 0.2$ & $16.0 \pm 0.2$ & $15.4 \pm 1.7$ \\
\hline
\end{tabular}

*Values are means $\pm \mathrm{SD}(n=3)$; C16:0, C18:0, C18:1, 18:2, C 20:0 and C18:3 are palmitic, stearic, oleic, linoleic, arachidic and linolenic acids, respectively. Less than $1 \%$ of myristic and behenic acids were also detected. 
Table 2. Mean area \% of FAMEs (fatty acid methyl esters)* and C18:1/C18:0 ratios in six roasted Brazilian coffee (Coffea arabica L.) varieties (Catuai, Catucaí, Bourbom, Mundo Novo, Rubí and Topázio), six roasted Brazilian corn samples**, three intentionally adulterated Brazilian coffee (Coffea arabica L.) samples and area \% of six roasted Brazilian coffee (C. arabica L.) brands**

\begin{tabular}{|c|c|c|c|c|c|c|c|c|c|c|c|}
\hline \multirow{2}{*}{$\begin{array}{l}\text { FAME } \\
\text { (elution } \\
\text { order) }\end{array}$} & \multirow{2}{*}{$\begin{array}{c}\text { Coffee } \\
\text { varieties }\end{array}$} & \multirow{2}{*}{$\begin{array}{c}\text { Corn } \\
\text { samples }\end{array}$} & \multicolumn{3}{|c|}{$\begin{array}{c}\text { Intentionally contaminated coffee } \\
\text { [Coffee:Corn/(m:m)] }\end{array}$} & \multicolumn{6}{|c|}{ Commercial coffee brand } \\
\hline & & & $95: 5$ & $90: 10$ & $80: 20$ & $\mathrm{i}$ & ii & iii & iv & $\mathrm{v}$ & vi \\
\hline C16:0 & $38.2 \pm 1.2$ & $14.6 \pm 0.2$ & $40.3 \pm 0.1$ & $39.6 \pm 0.3$ & $39.0 \pm 0.2$ & $37.9 \pm 1.3 \mathrm{c}^{1}$ & $38.5 \pm 1.3 b c$ & $37.8 \pm 0.5 \mathrm{c}$ & $40.4 \pm 1.0 \mathrm{a}$ & $40.2 \pm 1.2 \mathrm{ab}$ & $39.6 \pm 0.6 \mathrm{abc}$ \\
\hline $\mathrm{C} 18: 0$ & $8.3 \pm 0.1$ & $2.1 \pm 0.05$ & $8.2 \pm 0.04$ & $8.2 \pm 0.1$ & $7.6 \pm 0.1$ & $8.1 \pm 0.3$ & $7.90 \pm 0.18$ & $8.3 \pm 0.3$ & $8.3 \pm 0.3$ & $7.9 \pm 0.1$ & $7.6 \pm 0.2$ \\
\hline C18:1 & $8.6 \pm 0.3$ & $33.3 \pm 0.3$ & $8.3 \pm 0.1$ & $8.6 \pm 0.1$ & $9.1 \pm 0.04$ & $7.7 \pm 0.1 \mathrm{a}$ & $7.8 \pm 0.1 \mathrm{a}$ & $7.6 \pm 0.1 \mathrm{a}$ & $7.7 \pm 0.2 \mathrm{a}$ & $7.2 \pm 0.1 \mathrm{~b}$ & $7.1 \pm 0.2 b$ \\
\hline $\mathrm{C} 18: 2$ & $38.5 \pm 1.3$ & $47.5 \pm 0.3$ & $36.1 \pm 0.4$ & $36.6 \pm 0.3$ & $38.2 \pm 0.3$ & $39.9 \pm 1.8$ & $39.6 \pm 1.6$ & $39.7 \pm 0.8$ & $37.0 \pm 1.3$ & $38.2 \pm 1.0$ & $39.5 \pm 0.3$ \\
\hline $\mathrm{C} 20: 0$ & $3.6 \pm 0.2$ & $1.5 \pm 0.1$ & $4.0 \pm 0.1$ & $4.0 \pm 019$ & $3.7 \pm 0.1$ & $3.7 \pm 0.2$ & $3.6 \pm 0.2$ & $3.7 \pm 0.2$ & $3.9 \pm 0.1$ & $3.7 \pm 0.1$ & $3.5 \pm 0.1$ \\
\hline $\mathrm{C} 18: 3$ & $1.6 \pm 0.1$ & $0.6 \pm 0.05$ & $1.4 \pm 0.04$ & $148 \pm 0.02$ & $1.4 \pm 0.02$ & $1.6 \pm 0.1$ & $1.6 \pm 0.1$ & $1.7 \pm 0.1$ & $1.5 \pm 0.2$ & $1.6 \pm 0.2$ & $1.5 \pm 0.1$ \\
\hline $\begin{array}{l}\text { C18:1/ } \\
\text { C18:0 }\end{array}$ & $1.0 \pm 0.05$ & $15 . \pm .03$ & $1.0 \pm 0.01$ & $1.1 \pm 0.01$ & $1.2 \pm 0.01$ & $1.0 \pm 0.05$ & $1.0 \pm 0.04$ & $0.9 \pm 0.04$ & $0.9 \pm 0.01$ & $0.9 \pm 0.03$ & $0.9 \pm 0.02$ \\
\hline
\end{tabular}

*Values are means $\pm \mathrm{SD}(n=6)$; **Values are means $\pm \mathrm{SD}(n=3) ; \mathrm{C} 16: 0, \mathrm{C} 18: 0, \mathrm{C} 18: 1,18: 2, \mathrm{C}$ 20:0 and C18:3 are palmitic, stearic, oleic, linoleic, arachidic and linolenic acids, respectively; ${ }^{1}$ Mean commercial coffee brand $\%$ within a row followed by the same letter was not significantly different based on least squares means at $\mathrm{p} \leq 0.05$; Less than $1 \%$ of myristic and behenic acids were also detected.

as a marker to detect corn adulteration. We next analyzed six commercial coffee samples, knowing that only brand 3 was contaminated with $8.9 \%$ corn based on our new method based on $\gamma$-tocopherol as an adulterant marker ${ }^{6}$. The C18:1/ C18:0 ratios in adulterated samples were not higher than in the pure coffees. In all the cases, the ratios were lower than that of the average area $\%$ of the six coffee varieties. The lower C18:1/C18:0 ratios in commercial samples were most likely related to storage, processing, etc.

The discrepancy between the FAMEs and $\gamma$-tocopherol as an adulterant marker results can be possibly explained in the differences in the \% composition of the two markers used in this study. Average percentages of $\alpha-, \beta-, \gamma-$, and $\delta$-tocopherols in six unadulterated coffee varieties were 29.0, 61.7, 3.3 and 6.0, respectively, while average $\alpha$-, $\gamma$ - and $\delta$-tocopherol in six unadulterated corn samples were 3.6, 91.3 and 5.1, respectively. Thus, $\gamma$-tocopherol concentration values in coffee and corn were very different, i.e., 91.3 and 3.3, respectively. On the other hand, the average C18:1/C18:0 ratios in unadulterated corn vs. coffees were only 1.0 and 15.7 , respectively. Although the ratios were quite large, they were not sufficiently different to detect adulteration. Based on these data, it can be concluded that $\gamma$-tocopherol is a much better marker than FAMEs to detect coffee adulterated with corn.

\section{Conclusions}

We have thus determined, for the first time, the TAG and FA compositions of six coffee varieties used in our Brazilian coffee breeding program. The method was much quicker than the methods reported in the literature with complete characterization of our samples being possible in less than
6 min. This quick method will be useful to screen a large number of samples in our coffee program. These values should provide us insights while evaluating coffee quality. In addition, we have shown that FAMEs cannot be used as adulteration markers of corn in coffee. Also, based on our FAME and tocopherol adulteration results, it appears that for a compound to serve as a marker of adulteration in coffee, a very large difference (at least by a factor of $c a$. 30) should exist between its concentrations in the pure and adulterated samples. These conclusions should serve as guidelines for future development of coffee adulteration methods.

\section{Acknowledgments}

This study was supported in part by CAPES (Brazilian Federal Agency for Support and Evaluation of Graduate Education) through a scholarship awarded to G.N.J. Scholarship to G.N.J. from CNPq (National Council for Technological and Scientific Development)/Brazilian government is also gratefully acknowledged.

\section{References}

1. Belitz, H. D.; Grosch, W.; Schieberle, P.; In Lipids in Food Chemistry. Belitz, H. D., Grosch, W., Schieberle, P., eds.; Springer-Verlag: Heidelberg, 2004.

2. Akiyama, M.; Murakami, K.; Ohtani, N.; Iwatsuki, K.; Sotoyama, K.; Wada, A.; Tokuno, K.; Iwabuchi, H.; Tanaka, K. In Handbook of Flavor Characterization. Sensory, Analysis, Chemistry and Physiology. Deibler, K.D., Delwiche, J., eds.; Marcel Dekker: New York, 2004.

3. Assad, E. D.; Sano, E. E; Cunha, S. A. R.; Simões Correa, T. B.; Rodrigues, H. R.; Pesq. Agropec. Bras. 2002, 37, 211. 
4. Sano, E. E.; Assad, E. D.; Cunha, S. A. R.; J. Food Qual. 2003, $26,123$.

5. Fontes, A. S.; Bento, A. C.; Baesso, M. L.; Miranda, L. C. M.; Instrum. Sci. Technol. 2006, 34, 163.

6. Jham, G. N.; Winkler, J. K.; Berhow, M. A.; Vaughn, S. F.; J. Agric. Food Chem. 2007, 55, 5995.

7. Gunstone, F. D.; Harwood, J. L.; Padley, F. B. In The Lipid Handbook, $1^{\text {st }}$ ed.; Gunstone, F. D., Harwood, J. L., Padley, F. B., eds; Chapman Hall: New York, 1986.

8. Gamazo-Vázquez, A.; García-Falcón, M. S.; Simal-Gándra, J.; Food Control 2003, 14, 463.

9. Nikolova-Damyanova, B.; Velikova, R.; Jham, G. N.; Food Res. Int. 1998, 31, 479.

10. Martín, M. J.; Pablos, F.; González, A. G.; Valdenebro, M. S.; León-Camacho, M.; Talanta 2001, 54, 291.

11. Alves, M. R.; Casal, S.; Oliveira, M. B. P. P.; Ferreira, M. A.; J. Am. Oil Chem. Soc. 2003, 80, 511.
12. Casal, S.; Alves, A. R.; Mendes, E.; Oliveira, M. B. P. P.; J. Agric. Food Chem. 2003, 51, 6495.

13. Frega, N.; Bocci, F.; Lercker, G. ; Ind. Alimen. 1995, 34, 705.

14. Carrera, F.; León-Camacho, M.; Pablos, F.; González, A. G.; Anal. Chim. Acta. 1998, 370, 131.

15. Valdenebro, M. S.; León-Camacho, M.; Pablos, F.; González, A. G.; Martín, M. J.; Analyst 1999, 124, 999.

16. Bicchi, C. P.; Ombretta, M. P.; Pellegrino, G.; Vanni, A. C.; J. Agric. Food Chem. 1997, 45, 4680.

17. Martín, M. J.; Pablos, F.; González, A. G.; Food Chem. 1998, 66,365 .

18. Martín, M. J.; Pablos, F.; González, A. G.; Talanta 1998, 46, 1259.

19. González, A. G.; Pablos, F.; Martín, M. J.; León-Camacho, M.; Valdenebro, M. S.; Food Chem. 2001, 73, 93.

Received: October 29, 2007 Web Release Date: September 5, 2008 